\title{
GenRe PuBlics: AKTUIL MAGAZINE AND MIDDLE-CLASS YOUTH IN $1970 S$ INDONESIA
}

\section{Emma Baulch}

This article is a study, with revisionist intent, of a point in Indonesia's history that some analysts have referred to as its "capitalist revolution." 1 In it, I revisit the question of how this "revolution" gave birth to Indonesia's middle class, and the capacity of middle-class Indonesians to serve as agents of democratic change. A common presumption about Indonesia's middle class is that its growth was enabled by the counter-revolutionary ideology and development program of the New Order state (1966-98). I propose to draw attention to the important role of the press, and of popular music, both of which were radically reorganized on the advent of the New Order, to reconceptualize the origins of the middle class.

Emma Baulch is a Vice Chancellor's Senior Research Fellow at the Faculty of Creative Industries, Queensland University of Technology. This work was supported by the Australian Research Council under Grant DP0984681: "Middle Classes, New Media and Indie Networks in Post Authoritarian Indonesia" (2009-12), led by Professor Ariel Heryanto. I am grateful to Gde Putra for assisting me with the research for this article, and to an anonymous reviewer; to Bart Barendregt, John Cox, Made Darsana, Yan Djuhana, Peter Keppy, Theodore KS, Hamish McDonald, Denny MR, Andy F. Noya, Anthony Reid, Fariz RM, Kathy Robinson, Degung Santikarma, Patricia Spyer, Manunggal K Wardaya, and Made Widiantara for lending their insights into Aktuil and for providing comments at presentations based on earlier drafts.

${ }^{1}$ Richard Robison, Indonesia: The Rise of Capital (Sydney: Allen and Unwin, 1986), vii. 
The article studies how the pop music magazine Aktuil (1967-84) addressed its readers, and shows how this treatment allowed certain people to feel as if they were part of a tangible social entity that inhabited a middle social space, between the state and the masses. I position Aktuil in the context of the radical reorganization of the press and of popular music, which enabled the quiet evolution of the Indonesian middle class - a cohort constituted not only by musical taste, but also by the practice of reading. Aktuil gave rise to what I refer to as a genre public-a virtual social entity heralded into being by overlapping modes of address, that is, those that touched not only on a rhetoric of print, but also on discourses of popular music genres.

By proposing that the middle class was a virtual entity, the imagination of which was enabled by the reorganization of the press and of popular music, this essay departs from a dominant perspective that attributes to the state a pivotal role in the tangible growth of the middle class in the 1970s. In the late-1980s and early 1990s, a surge of literature appeared on the subject. Many observers of the Indonesian middle class aver that the New Order provided the political and economic conditions for middle-class growth, ${ }^{2}$ and quite a lot of scholarly activity has focussed on quantifying that growth. ${ }^{3}$ Scholars disagreed about the nature and definition of class, ${ }^{4}$ and about the relationship between middle-class groups and democratization. ${ }^{5}$ But, as Aspinall argues in a recent review, similar assessments of the role of the state emerge across this body of work: "We can now see that despite theoretical and philosophical differences, and often very bitter disagreement, there was underlying agreement

${ }^{2}$ Vedi R. Hadiz and Daniel Dhakidae, "Introduction" in Social Science and Power in Indonesia, ed. Vedi R. Hadiz and Daniel Dhakidae (Jakarta and Singapore: Equinox and Institute of Southeast Asian Studies, 2005), 21-22; Dan Lev, "Intermediate Classes and Change in Indonesia: Some Initial Reflections," in The Politics of Middle Class Indonesia, ed. Richard Tanter and Kenneth Young (Clayton: Centre of Southeast Asian Studies, Monash Papers on Southeast Asia No 19, 1990), 29; Richard Tanter and Kenneth Young, "Introduction," in The Politics of Middle Class Indonesia, ed. Richard Tanter and Kenneth Young (Clayton: Centre of Southeast Asian Studies, Monash Papers on Southeast Asia No 19, 1990), 7.

${ }^{3}$ Harold Crouch, "The Missing Bourgeoisie: Approaches to Indonesia's New Order," in Nineteenth and Twentieth Century Indonesia: Essays in Honour of Professor J. D. Legge, ed. David Chandler and Merle Rickleffs (Melbourne: Centre of Southeast Asian Studies, Monash University, 1986); Howard Dick, "The Rise of a Middle Class and the Changing Concept of Equity in Indonesia," Indonesia 39 (1985): 71-92; Hadi Jaya, "Dari Redaksi," in Kelas Menengah Bukan Ratu Adil, ed. Hadi Jaya (Yogyakarta: Tiara Wacana, 1999), viixxvi; Richard Robison, "The Middle Class and the Bourgeoisie in Indonesia," in The New Rich in Asia: Mobile Phones, McDonalds, and Middle Class Revolution, ed. Richard Robison and David S. G. Goodman (London: Routledge, 1996), 70-104; Happy Bone Zulkarnain, Faisal Siagian, and Laode Ida, "Kelas Menengah Digugat: Catatan Editor," in Kelas Mengenah Digugat, ed. Happy Bone Zulkarnain, Faisal Siagian and Laode Ida (Jakarta: Fikahati Aneksa, 1993), 9-26.

4 See: J. A. C. Mackie, "Money and the Middle Class," in The Politics of Middle Class Indonesia, ed. Tanter and Young, 96-122; Richard Robison, "The Problems of Analysing the Middle Class as a Political Force in Indonesia," in The Politics of Middle Class Indonesia, ed. Tanter and Young, 137-47; Mohamad Slamet, "Comment on Jamie Mackie's "Money and the Middle Class," in The Politics of Middle Class Indonesia, ed. Tanter and Young, 123-26; and Benny Subianto, "Konsep Kelas Menengah Indonesia: Konsep yang Kabur," in Kelas Menegah Bukan Ratu Adil, ed. Hadi Jaya, 17-24.

${ }^{5}$ See: Lev, "Intermediate Classes and Change in Indonesia," 25-43; R. William Liddle, "The Middle Class and New Order Legitimacy," in The Politics of Middle Class Indonesia, ed. Tanter and Young, 49-52; Hadi Jaya, ed., Kelas Menengah Bukan Ratu Adil, 69-186; Richard Robison, "The Problems of Analysing the Middle Class as Political Force in Indonesia" in The Politics of Middle Class Indonesia, ed. Tanter and Young, 127-37; and Zulkarnain et al., Kelas Menengah Digugat. 
among analysts on both the left and the right about the strength, authority, and independence of the state." 6

Some of these works serve as the basis for important contributions to contemporary debates about the processes of regime change and the quality of democracy in contemporary Indonesia, which have centered on arguments about whether the Indonesian polity should be understood as one primarily shaped by oligarchic rule. ${ }^{7}$ Richard Robison has consistently argued that the middle class never massed as an effective political force during the New Order period, and that this can be understood as a function of its evolution, from the late-1960s, as a class very much integrated with state power. ${ }^{8}$ Consequently, rather than democratization, regime change has entailed the consolidation of the "predatory state and private oligarchies." 9 Others have argued that there is much that this argument omits. In his reappraisal of Robison's assessment of state-capitalist class relations under the New Order, for example, Aspinall concludes by stating: "Looking at capital is not enough. The Indonesian masses and middle classes too are starting to write their own history, and we need to broaden our analytical focus accordingly." 10

While debates about the role of the middle class in overthrowing the New Order regime and in shaping the post-Suharto polity have blossomed, they have been very much focused on the present or recent past. The "underlying agreement" about the New Order state's pivotal role in the genesis of the Indonesian middle class remains largely unrevised, and this leaves some important questions unanswered. If Suharto's overthrow were testimony to the assertiveness of societal forces, what historical conditions enabled such forces to recognize their power? Is it possible that scholars writing in the 1980s of the evolution of the middle class missed signs of its agency and autonomy? If we are to turn our focus away from capital accumulation, what conceptual tools would be aptly applied to an exploration of such possibilities?

A study of Aktuil provides an opportunity to employ fresh conceptual tools and develop an alternate theory of the genesis of the middle class in the 1970s. Aktuil spoke to a varied group of urban-dwelling youth, sometimes with little in common but

${ }^{6}$ Edward Aspinall, "The Triumph of Capital? Class Politics and Indonesian Democratisation," Joumal of Contemporary Asia 43, 2 (2013): 227.

${ }^{7}$ For example, see: Vedi Hadiz, ed., "Special Feature Section: Capitalism and Indonesia's Democracy," Journal of Contemporary Asia 43, 2 (2013); and Michele Ford and Thomas B. Pepinsky, "Beyond Oligarchy? Critical Exchanges on Political Power and Material Inequality in Indonesia," in "Special Issue: Wealth, Power, and Contemporary Indonesian Politics," ed. Michele Ford and Thomas B. Pepinsky, Indonesia 96 (October 2013): 1-9.

${ }^{8}$ In 1990 Robison wrote: "Whilst in the last decade the physical ranks of the middle classes have swelled with the inflow of oil money, its liberal elements have been hammered into political ineffectiveness by the regime on the campuses, in the media, and within the state apparatuses." Robison, "The Problems of Analyzing the Middle Class as a Political Force in Indonesia," 134.

${ }^{9}$ Vedi Hadiz and Richard Robison, "Neo-liberal Reforms and Illiberal Consolidations: The Indonesian Paradox," Joumal of Development Studies 41, 2 (2005): 220-41. See also: Vedi R. Hadiz and Richard Robison, "The Political Economy of Oligarchy and the Reorganization of Power in Indonesia," Indonesia 96

(October 2013): 35-56; and Jeffrey A. Winters, "Oligarchy and Democracy in Indonesia," Indonesia 96 (October 2013): 11-33.

${ }^{10}$ Edward Aspinall, "The Triumph of Capital? Class Politics and Indonesian Democratisation," Journal of Contemporary Asia 43, 2 (2013): 240. 
an advanced level of print literacy. ${ }^{11}$ To understand the political significance of these disparate groups' imagined assembly via Aktuil, I turn to work on publics. Since the publication of Anderson's Imagined Communities and of Habermas's The Transformation of the Public Sphere, it has become increasingly common for scholars to investigate the relationship between mass media and political subjectivity through recourse to the concept of publics. ${ }^{12}$ At the heart of this body of scholarship lies an understanding that the social power of texts derives from their ability to address people in a way that enables them to imagine themselves as members of a community of strangers who, although physically distant from one another, act collectively by inhabiting the texts' paths of circulation. Treating the Indonesian middle class as a public, rather than as a tangible element of social structure, is useful because it broadens the field of inquiry into the genesis and currency of political ideas. Using publics to understand political organization brings three neglected areas into the frame: culture, media, and theory. One cannot "think with" publics without thinking about the politics of the language by which mass media consumers are addressed, and of the technologies that mediate that address. Publics, then, open space for acknowledging the cultural arena born of the capitalist revolution - in this case, pop music and consumer culture-as fertile grounds for the growth of political ideas. But they also provide a conceptual framework by which the social force of those ideas can be theorized.

Indeed, the implications of mass media for democracy have been crucial to the development of critical theory over the last half-century. According to Michael Warner, only a faith in the existence of publics can render notions of political will and consumer agency plausible. "Without a faith, justified or not, in self-organized publics, organically linked to our activity in our very existence, capable of being addressed, capable of action, we would be nothing but the peasants of capital."13 Warner's discussion draws attention to the elusive power of publics. Wherever there is mass media, there is a faith in the existence of a collective capable of being addressed by that media. In the Aktuil case, such delicate politics are discernable in the way the magazine depicted youth. In particular, the dogged persistence of the

${ }^{11}$ My research suggests readers were a mix of children of petty bourgeoisie, high-ranking military officers, and low-ranking civil servants, including university lecturers and village heads. Denny Sabrie, the founder of Aktuil, was the son of a high-ranking civil servant (and presumably a military man). Graphic stories in Aktuil depict the ideal middle-class domestic environment as a high-ranking officer's home in a military complex, and some of the letters to the editor published in the magazine suggest that some readers lived in such homes. But not all readers were people of means, or from military families. Sabrie came from a family of considerable means, but two of my informants had been left fatherless after the mass killings of leftists in 1965 66, and they were not from rich families. One of them put himself through school by selling cakes in the school yard.

12 See: Benedict Anderson, Imagined Communities (London: Verso, 1983); Francis Cody, "Publics and Politics," Annual Review of Anthropology 40 (2011): 37-52; Jodi Dean, "Cybersalons and Civil Society: Rethinking the Public Sphere in Transnational Technoculture," Public Culture 13, 2 (2001): 243-65; Jurgen Habermas, The Structural Transformation of the Public Sphere: An Enquiry into a Category of Bourgeois Society (Cambridge: MIT Press, 1991); Charles Hirschkind, The Ethical Soundscape: Cassette Sermons and Islamic Counterpublics (New York: Columbia University Press, 2006); Michael Warner, "Publics and Counterpublics," Public Culture 14, 1 (2002): 49-90; and Michael Warner Publics and Counterpublics (New York: Zone Books, 2002).

${ }^{13}$ Michael Warner, "Publics and Counterpublics," 69. Habermas, too, draws attention to the importance of coffee, the press, and the proliferation of places to consume these in seventeenth-century Europe in the beginnings of an ideal public sphere that "compelled public authority to legitimate itself before public opinion" (Habermas, The Structural Transformation of the Public Sphere, 25). 
notion of youth as historical agents, or pemuda, in the magazine, suggests that they were by no means "hammered into political ineffectiveness." 14

Pemuda literally translates as "youth," but the term specifically denotes youth at the forefront of social change, and does so by harking back to two distinct periods of young people's political mobilization: the 1928 generation of highly educated, nationalist youth, and the 1945 generation of revolutionary youth who took up arms against the Dutch. From Aktuil's outset, pemuda played a crucial role in providing readers with a historical position from which to orient themselves toward the West. ${ }^{15}$

Pemuda refers to men, but the gendered dimensions of Aktuil's portrayal of middleclass youth changed throughout the magazine's career. It reveals a progressive masculinizing of the notion of critical youth as the New Order wore on. In early editions, women featured prominently, and the figure of the mobile young woman plays a primary role in articulating the magazine's message. Later editions began to pay more attention to Indonesian men, both by putting forward the image of young man with a rock sensibility as an ideal figure, and by directly addressing a young, male, middle-class reading public. In this way, Aktuil created a new archtype, for the overlap of rock and print in the magazine had the effect of bringing together the two distinct legacies of pemuda mentioned above, and of creating space for this new composite in a new world full of consumption and exchange, and of commodities.

\section{Not Politically Evacuated}

Aktuil was established in 1967 as a biweekly magazine, and became the first popular-music publication to emerge during the transition from Sukarno's Guided Democracy (1959-66) to Suharto's New Order (1966-98). It was the brainchild of a young man named Denny Sabrie, an avid Deep Purple fan, and the son of Sabrie Gandanegara, the vice governor of the province of West Java (1966-74); and Toto Rahardja, who managed a dance troupe. The magazine Diskorina, where the younger Sabrie was formerly based, did not afford him the opportunity to write serious rock criticism, hence his idea to establish Aktuil in Bandung, West Java. ${ }^{16}$ Aktuil survived until $1984 .{ }^{17}$ At its peak, in 1973-74, it boasted a circulation of $126,000^{18}$ up to triple that of Tempo, the celebrated news magazine, which up to the late 1970s had a

${ }^{14}$ Robison, "The Problems of Analyzing the Middle Class as a Political Force in Indonesia," 134.

15 Other writers have drawn attention to the importance of pemuda in the development of student activism during the New Order; see, for example, Edward Aspinall, Opposing Suharto: Compromise, Resistance and Regime Change in Indonesia (Stanford: Stanford University Press, 2005); and Doreen Lee, Activist Archives: Youth Culture and the Political Past in Indonesia (Durham and London: Duke University Press, 2016). But Aktuil's power lay in its ability to draw this trope into the everyday of pop culture consumption: to address not just activists, but middle-class youth in general.

${ }^{16}$ Mohamad Mulyadi, Industri Musik Indonesia: Suatu Sejarah (Bekasi: Koperasi Ilmu Pengetahuan Sosial, 2009), 52.

${ }^{17}$ See: Mulyadi, Industri Musik Indonesia; Soleh Solihun, "Perjalanan Majalah Musik di Indonesia" (skripsi untuk gelar Sarjana Komunikasi, Universitas Padjadjaran, Fakultas Ilmu Komunikasi, Jurusan Ilmu Jurnalistik, 2004 ["The Journey of the Indonesian music press," dissertation for Bachelor of communication degree, Padjadjaran University, Communications Faulty, Journalism Department, 2004]); and Agus Sopian, "Putus Dirundung Malang” [Discontinued, dogged by bad luck], Pantau, Tahun II, Nomor 016 (August 6, 2001); http://www.pantau.or.id/?/=d/45, accessed November 20, 2007.

${ }^{18}$ Sopian, “Putus Dirundung Malang." 
circulation of "around 25,000 or $40,000 . " 19$ By 1977, sales of Aktuil had dropped to thirty thousand, and by 1979 they were merely three to four thousand. In 1979 , the title was sold to Sondang Pariaman Napitupulu, its headquarters moved to Jakarta, and its music-related and literary content were dropped..$^{20}$

I based this essay's analysis on 126 editions of Aktuil dated from 1967-74. Editions 1-46 (1967-69) are in A5 (page) format (148 x $210 \mathrm{~mm}$; about $5.8 \times 8.25$ inches) and priced between Rp50 and Rp75 (approximately 25-35 US cents). Editions 67-157 (1971-74) are in A4 format (210 × $297 \mathrm{~mm}$; about $8.25 \times 11.7$ inches) and priced at Rp150 (approximately 40 US cents). ${ }^{21}$ Aside from the page size, there are other differences between earlier and later editions, which is why I discuss them separately.

When I first leafed through the early editions of Aktuil I had acquired, they reminded me very much of some of the Indonesian underground fanzines I had encountered in the 1990s, or one of the several magazines devoted to Asian pop that circulate in today's Indonesia. There is nothing of the ordered, sublimely glossy, exquisitely laid out and neatly framed pages of Rolling Stone magazine (which later editions of Aktuil resemble). Each page contains large chunks of text and the photographs are small, and raggedly cropped. Some of the captions are written by hand. There is a reveling in the textural possibilities of type, with frequent use of capitals and running stops in the body of the text. Between ten and sixteen pages in each issue is reserved for the lyrics of Indonesian language and English language pop songs. Even the advertisements appear not as images, but as chunks of text on a page devoted to "Pop Ads." These early editions do not appear as an exhibition of images and text around a theme in a quiet and carefully ordered space. They are more like the scene of a rag-tag choir, whose members sing the same song but in different languages and at different tempos.

What kinds of readers did this incongruous choir address, and what were the political implications of this address? Reading through the first three editions of Aktuil, one gains a strong sense of the magazine as a space devoted to addressing a community of youths who are distinctive for their lifestyle choices, which set them apart from their parents and other authority figures. Short stories and graphic dramas recount conflicts between parents and their teenage children over their chosen partner, and some of them openly depict scenes of sex before marriage. ${ }^{22}$ Editorials criticize the authorities' education policies and corruption in the administration of

${ }^{19}$ Letters to the editor and the life stories of those former readers I interviewed for this essay (one grew up in Jayapura and another in Denpasar) show that Aktuil's circulation was not limited to Java; it extended across the archipelago. Circulation figures are from Janet Steele, Wars Within: The Story of Tempo, an Independent Magazine in Soeharto's Indonesia (Jakarta and Singapore: Equinox and Institute of Southeast Asian Studies, 2005).

${ }^{20}$ Sopian, "Putus Dirundung Malang." Sopian cites editor Remy Silado, who surmises that the reason for waning sales was that the editors' tastes had aged beyond what appealed to the sixteen-to-seventeenyear-old readership.

21 https://fred.stlouisfed.org/series/CCUSSP02IDQ650N, accessed October 5, 2016.

${ }_{22}^{22}$ See: "Aku Lahir Membawa Dosa dan Kejahatan," Aktuil 57 (1970): 44-46; Rio Purbaya, "Balada Sebuah memori," Aktuil 52 (1970): 37-39; Rio Purbaya, "Balada Sebuah memori," Aktuil 52 (1970): 44-46; and Didiek W, "Kau Laki Laki Pengecut, Hendra," Aktuil 57 (1970): 12-13. 
schools, and refer to "our generation of schoolchildren." 23 Features directly align popmusic consumption with young people's inherent desire for freedom from their parents. $^{24}$

Of particular interest is Aktuil's choice of language to sketch the category of youth, and the ways in which young Indonesian women are represented in early editions. In both respects, Aktuil problematizes key dimensions of New Order-era pop Indonesia as interpreted by scholars. There is a tendency in scholarship examining Western style pop, or pop Indonesia, to interpret the cultural practices associated with this genre as either politically benign or pro-regime. According to Siegel, pop Indonesia-devoted magazines for youth propagated apolitical youth ideals that suited the regime's interest in maintaining order and stability. Based on his analysis of Topchords magazine, he argues that new terms were coined in the New Order period to denote ideal youth. Specifically, the term remaja, which means teen, came to replace that of pemuda, which carries political connotations "of the sort the Soeharto regime has made difficult." 25

Aktuil, however, reveals that the term pemuda was very present in writing about pop music in magazines devoted to youth. For example, a 1969 feature article entitled "Pop Music Yields Creativity, Art and Revolution"26 serves as a prime example of how Aktuil addressed youths as distinct from their parents, and it employs the term pemuda liberally. The article firmly differentiated between "the old establishment who are the pawns of the power-holders" and the young, "who want to free themselves from the imprisoning chains that so disgust them." 27 It calls on the young (pemuda) to wage a nonviolent, anti-establishmentarian war through music and fashion. Gde Putra, who assisted me with the research for this essay, shared with me his insights into how the article attempts to redefine the term pemuda, and to align it with consumption of Western popular culture and points-of-view-the article hints at pop music's function as a soft power to aid the counter-revolution. But what is equally interesting about the article is that it does not clearly detach from its pemuda legacy. It does attempt to associate pemuda with pop consumption. There is no easy distinction in Aktuil between Western-pop-consuming, apolitical youth and revolutionary youth, critical of Western influence of the preceding period. The magazine calls out to a hybrid: pemuda-teen.

\section{Destination Somewhere}

Of further interest is the female form that Aktuil's pemuda-teen assumes. Early editions of the magazine were primarily devoted to celebrating Western pop, and included many images of the West and Western people. They included reviews of

\footnotetext{
${ }^{23}$ Johanes Car, "Kemanakah Generasi Kami Tuan Bawa," Aktuil 52 (1970): 89.

${ }^{24}$ Sonny Surya, "Musik Pop: Media Jang Telah Melahirkan Kreatifitas Serta hasil Seni dan Revolusi," Aktuil 30 (1969): 10-11.

${ }^{25}$ See: James Siegel, Solo in the New Order (Princeton: Princeton University Press, 1986), 201; Jeremy Wallach, Modern Noise, Fluid Genres: Popular Music in Indonesia, 1997-2001 (Madison: University of Wisconsin Press, 2008), 252-53; and Yampolsky, "Hati Yang Luka," 9-10.

${ }^{26}$ Surya, "Musik Pop: Media Jang Telah Melahirkan Kreatifitas, Serta Hasil Seni dan Revolusi" (Pop music gives rise to creativity, art, and revolution), Aktuil 30 (1969): 10-11.

${ }^{27}$ Kaum tua establishment adalah manusia2 jang hidupnja hanya didikte penguasa. Sedang mereka kaum muda ingin melepaskan diri dari belenggu jang selalu mengikat dam terasa memuakkan.
} 
Hollywood films, publication of Western pop songs' lyrics, gossip about Western bands, and reports of shows in the United States and the United Kingdom. Western musicians are shown to sport defiantly long hair - an antidote, perhaps, to the Indonesian military ideal, but this style of coiffure never settles down on the heads of Indonesian male musicians, who, in fact, are scarcely present in early editions of the magazine. The scarcity of images of Indonesian performers in Aktuil may seem to position Indonesians as spectators, rather than producers, and, to more broadly infer young Indonesians as consumers of the West, rather than agents of their own destiny. But at the same time, reading these early editions is not like bathing in images of the West. Indonesian women are strikingly present.

Women, sometimes scantily clad or smoking in risqué fashion (or both), adorn the front and back covers of many early editions. They are never the subject of the apparently much-sought-after poster in the centerfold, but Indonesian female singers appear as subjects of feature articles. ${ }^{28}$ In Aktuil, women are shown to have complex opinions and to be sexually active. They are mobile, sometimes transnationally so; they are runaways; they are theater critics; they serve alongside men as office holders in the Aktuil fan club, revealing that women, too, read Aktuil. They also appear as the main protagonists in short stories penned by men, which explore moral considerations surrounding sex and arranged marriages. Sometimes these women are sexually active before marriage (although generally this sexual activity does not serve them well), and sometimes they enter into painful and prolonged conflicts with their mothers regarding relationships and partner choices. ${ }^{29}$

Indeed, arranged marriage is a consistent theme in the struggles of the women represented in Aktuil. It is the main reason for their interest in premarital flight from the family home. I have no way of knowing whether they are genuine letters, or penned by the magazine's editors, but the following letters, published in the feature entitled "Help" in a 1969 edition, highlight how the magazine strived to use female figures to portray generational conflict:

Susie, mum and dad want you to come home. The problem is resolved. We recognize we were wrong and that you must follow your heart to find your soul mate. You should bring Herman home and immediately ask for dad's blessing. Come home Sus! Longing parents, Somatri, Bandung ${ }^{30}$

Mami, Lily has left home to follow her heart. Don't try to find me. One thing is clear, I am choosing my own man. We will be responsible for ourselves now, we

${ }^{28}$ See: Hasanta, "Tidak Mau Banjak Diberi Komentar," Aktuil 52 (1970): 45; Hendrik Z., "Tjorat-tjoret Ernie: Kita Mampu Menandingi Artis Eropa," Aktuil 30 (1969): 3-4; Oey Hian Hoo, "Vivi Sumanti," Aktuil 56 (1970): 6; Ratna press, "Ellya Lindawati jang Bertjit-tjita Gede," Aktuil 30 (1969): 47; "Tinny," Aktuil 52: 3; and "Wajah Depan Maria," Aktuil 56 (1970): 39.

${ }^{29}$ Purbaya, "Balada Sebuah memori," 37-39, 4446.

${ }^{30}$ Susi, ajah dan ibu mengharap untuk lekas pulang. Persoalannja sudah beres., dan telah jkami insjafi sepenuhnya. Memang ibu dan ajah telah keliru kerna soal djodoh adalah sama dengan pati. Sebaiknja nanti Susy membawa serta Herman menghadap ajah untuk memnentukan kapan melangsungkan pernikahanmu. Lekaslah pulang Sus!! Orang tua jang rindu. Somantri, Bdg. Aktuil 30 (1969), 53. 
realize we are no longer considered part of the family. Please pray for us. Naughty child, destination somewhere ${ }^{31}$

A powerful picture to emerge from scholarship on women's public presence during the New Order period is that it was "built on an excessively masculine power obsessed with control and women's submission ... The 'woman' was no longer defined as a comrade in the revolutionary struggle; under the New Order, she was a submissive wife and devoted mother." 32 But the figures of Susie and Lily complicate this picture, and shed light on a contrasting development. Under military rule, a range of narratives of women's lives circulated, including those that ran counter to the "norm," the domestication of women. These counter narratives can be read as instances of excess, resulting from the military's reliance on pop, especially feminized pop, to evince the counter-revolutionary modern.

\section{Western Pop and the Counter-revolutionary Modern}

Several writers have noted the important role Western-style pop music played in the military's efforts to convey a sense of ideological rupture and cultural novelty, following the overthrow of Guided Democracy and the violent suppression of the left. ${ }^{33}$ Such close ties can only be understood in the light of the prohibitions placed on the airing of North American and European popular music and film in the national public space during the course of Guided Democracy (1959-65). In 1959, Sukarno delivered a speech in which he espoused the need to take steps to protect national culture from foreign influences. Initially, these steps included banning Western commercial pop on the national public radio, Radio Republik Indonesia (RRI). Further steps to protect the national culture were taken in 1963, when a Presidential Decision forbade any public airing of rock and roll, and in 1964, when police operations undertaken in the provincial city of Bandung were aimed at publicly burning Elvis Presley records and "disciplining" young men with shaggy, Beatles-style haircuts. In 1965, members of the band Koes Bersaudara were arrested after attending a house party where they sang the Beatle's song "I Saw Her Standing There."34

${ }^{31}$ Mami, kini Lily sudah pergi dari rumah untuk mengikuti hati Lily sendiri. Djanganlah mamie dan papie mentjoba2 mentjari di mana kini Lily berada. Hanya satu jang djelas, Lily ikut dengan laki-laki pilihan sendiri. Ini semua mendjadi tanggung djawab kami berdua, walau kami tidak dianggap sebagai keluarga. Mohon doa restu saja. Anak jang bandel, destination somewhere. Ibid.

32 Saskia Wieringa, "The Birth of the New Order State in Indonesia: Sexual Politics and Nationalism," Journal of Women's History 15, 1 (2003): 72. This picture is complicated, it has to be noted, by the fact of military sponsorship of female pop bands. On stage, Dara Puspita hardly looked submissive.

33 See: Budi Setiyono, "Ngak Ngik Ngok," Pantau, Tahun II, Nomor 018 (2001): 38-47; Sopian, "Putus Dirundung Malang"; Mulyadi, Industri Musik Indonesia: Suatu Sejarah; and Krishna Sen, "Radio Days: MediaPolitics in Indonesia," The Pacific Review 16, 4 (2003): 573-89.

${ }^{34}$ Frederick attributes the bannings to the influence of the leftist cultural organization, Lekra (Lembaga Kebudajaan Rakjat, Institute for the People's Culture); see William Frederick, "Rhoma Irama and the Dangdut Style: Aspects of Contemporary Indonesian Popular Culture," Indonesia 32 (1982): 103-30. Sen and Weintraub both note how student-run pirate radio stations flouted the ban, and Weintraub stresses the important role of commercial pop from the United States and Europe in influencing Indonesian composers and performers during this time. See: Sen, "Radio Days," 573-89; and Andrew Weintraub, Dangdut Stories: A Social and Musical History of Indonesia's Most Popular Music (New York: Oxford University Press, 2010), 57. Mulyadi avers that the rules of these prohibitions were neither clear cut nor consistently applied. Sometimes, musicians performing the forbidden styles appeared as guest stars at state sponsored 
After September 30, 1965, the army began tactically to undermine the ban on public performances of Western-style music. Krishna Sen notes how anti-Sukarnoist student activists used pirate radio stations to broadcast both anticommunist messages and Western pop music, and were protected as they did so by the military. She writes:

One of the best known [of such pirate radio stations], Radio Ampera, set up by activists, including brothers Soe Hok Gie and Arief Budiman, broadcast for a time from the home of Mashuri, then a next-door neighbor and trusted political ally of Soeharto. While technically illegal, anticommunist and anti-Sukarno broadcasts were not just condoned but often actively aided by ascendant factions of the military. While based at Mashuri's residence, Radio Ampera, for instance, was openly protected by pro-Soeharto troops ... The student stations also flaunted [sic; flouted] RRI's ban on certain types of Western pop music, by broadcasting popular songs from prohibited bands like the Beatles and Rolling Stones. ${ }^{35}$

Additionally, Mulyadi states that the military used state-prohibited Western-style commercial pop music to interest people in a new regime of governance, beginning with the mass killings and arrests of 1965-66. He contends that the Body for Cooperation between Artists and the Army Strategic Command (Badan Kerjasama Seniman-Kostrad) promoted a series of "soldier stages" (panggung prajurit), inviting (as part of an "effort towards moral transformation") artists to perform the kinds of songs that had been banned, ${ }^{36}$ and details how, from late 1965 through the early 1970s, live and telecast (on public television, TVRI) musical events were used to associate the military uniform with pop music. The military uniform was ubiquitous on TVRI's music show, Cameria Ria, since after 1965 senior military personnel established and played (dressed in their uniforms), or sponsored, Western pop bands. It was that kind of cultural environment that yielded the following lyric, published in RRI's magazine in 1967:

Camouflage-shirted Guy ${ }^{37}$

Ah ah ah ... how lovely

To sit by the shore

And dream of

My camouflage-shirted guy

An army man

In a camouflage shirt

With his beret on

Oh, he's so handsome and brave

live events, or as contestants in the national public radio song contest (Mulyadi, Industri Musik Indonesia, 14). Budi Setiyono's piece documents the arrest of Koes Bersaudara members (Setiyono, "Ngak Ngik Ngok").

${ }^{35}$ Sen, "Radio Days," 578.

${ }^{36}$ Mulyadi, Industri Musik Indonesia: Suatu Sejarah, 20.

${ }^{37}$ Cited in ibid., 29. Si Badju Loreng: Ah ah ah ... indah sekali / Duduk di pinggir pantai / Sambil kukenangkan /

Kisah si badju loreng / Seorang anggauta ABRI / Memakai badju loreng / Lengkap dengan baretnya / Aduh gagah perkasa / Sangat menawan hati / Kebanggaan s'luruh bangsaku / Ia kan kukagumi / Tetap kuingat djasamu 
He stole my heart

The pride of my country

I will be in awe of him

I will always remember your service

Aktuil was established in the midst of the military's concerted incorporation of pop into its performance of newness, and in some ways Aktuil's address of a new kind of youth overlapped with the military project of using pop to evince the novelty of New Order rule. ${ }^{38}$ Both the military project and early editions of Aktuil focused on women, for example. The late 1960 s and early 1970 s saw the rise to prominence of a number of female rock bands and soloists, and in promotional photographs, these women are often shown donning military uniform or accompanied by soldiers. ${ }^{39}$ "Camouflageshirted man," for example, was penned and performed by Lilis Suryani, and included in an album the cover of which features her in camouflage. Dara Puspita, the foremost all-female rock band of the period, was often photographed in military uniform. In 1965, the Army Strategic Command invited the Dutch band The Blue Diamonds to perform a series of shows at the Hotel Indonesia, and Dara Puspita appeared as the opening act.

Students, then, allied with the military in order to overthrow Guided Democracy, and all-female pop bands provided that effort with a soundtrack. Together, all-female bands and the students furnished regime change with an air of fun-loving moral elevation, helping to paper over the violent reinterpretation of modernity that proceeded with the regime's establishment. The figure of Lily-the letter-writing naughty daughter whose destination was uncertain-may be seen as consistent with the spirit of youth that was given space to blossom because it endorsed generational change and historical rupture. But this does not mean that in very respect the spirit of youth fell into step with the regime's hopes for a compliant populace.

As it happens, Dara Puspita also performed shows sponsored by Aktuil, including their 1971-72 "spectacular" tour of the country. Aktuil, however, never published photographs of the military personnel or of musicians wearing military uniform. The absence of the military uniform in Aktuil reveals the tensions resulting from foregrounding women in the military's notion of the counter-revolutionary modern. In Aktuil - very much a child of the counter-revolution-women broke free of the military uniform and, wearing civilian clothes, insisted on defying their fathers.

Moreover, dramatizations of filial defiance extended beyond Aktuil, and endured in other artistic productions well into the 1970 s. ${ }^{40}$ In pop composer Zakaria's songs from

38 Indeed, Aktuil was by no means isolated from military circles. Denny Sabrie's father was presumably a military man and may have been responsible for securing the publishing license for the magazine. Sopian notes that Aktuil's publishing license was issued by the West Java Regional War Authority (Penguasa Perang Daerah Jawa Barat), "a very powerful military organization." Sopian, "Putus Dirundung Malang," np (web-based).

${ }^{39}$ Private correspondence with Manunggal K. Wardaya, November 23, 2015. Wardaya has researched in detail and written at length about the 1960 s all-female band Dara Puspita, including their success in Europe and Indonesia.

${ }^{40}$ See also Farid's discussion of generational conflict caused by forbidden love in novels published by the Balai Pustaka, the colonial publishing house established to counter the wave of socialist-oriented Malay literature in the early twentieth century, and also his discussion of the concept of romantic love that was featured in the earlier proto-nationalist literature. Hilmar Farid, "Meronta dan Berontak: Pemuda dalam 
the 1970s, which consist of dialogues between lovers, or between fathers and daughters, women are also portrayed as pioneers of cultural critique. As Weintraub notes, in Zakaria's compositions, women exist as public beings who make plain their desire to venture beyond the home. Young girls want to have careers, and married women want to have affairs. ${ }^{41}$ Like Aktuil's portrayals of women's thoughts and feelings, Zakaria's sharply contrast with those apparent in "Camouflage-shirted guy," sung from the perspective of a woman gazing adoringly at a soldier. One of Zakaria's songs, "Don't Sit in Front of the Door," proceeds thus:

Father: Don't sit in front of the door

Listen to your father's words

When will I be able to marry you off?

Daughter: You're good at talking

Hearing you makes me embarrassed

Because I want to go to school

And other things [i.e., marriage] have to wait.

Father: Good, but listen to me

A young girl does not need to be smart

As long as she can write and read

Even if she achieves a good education

In the end she still works in the kitchen.

Daughter: Father don't say that

Girls nowadays have to move forward

If I can become a doctor

I can take care of children and grandkids. ${ }^{42}$

By 1971, Aktuil's readers were being addressed in new ways, reflecting changes at the magazine. In 1970, Deny Sabrie appointed the writer Remy Silado as editor. ${ }^{43}$ As a result, the literary content of the magazine began to change. At the same time, Aktuil also appointed Maman Husen Somantri as designer, and his idea to include bonuses such as stickers and iron-ons in each edition of the magazine was adopted and proved successful. Circulation soared as a result.

Sastra Indonesia," Prisma 30, 2 (2011), hilmarfarid.com/wp/meronta-dan-berontak-pemuda-dalam-sastraindonesia/11/09/15, accessed July 12, 2015.

${ }^{41}$ Andrew Weintraub, "Melayu Popular Music in Indonesia, 1968-75," in Sonic Modernities in the Malay World: A History of Popular Music, Social Distinction and Novel Lifestyles (1930s-2000s), ed. Bart Barendregt (Leiden: Brill, 2014), 179.

${ }^{42} \mathrm{~F}$ : Jangan suka duduk di depan pintu / Coba ayu dengar babeh bilangin / Nanti jadi lama dipungut mantu / Sampe kapan bisa babeh ngawinin

D: Emang babeh paling sih bisa aje / Aye dengernya ih jadi malu / Kapan aye masih mau sekolah / Soal gituan tuh sih entar dulu

F: Bagus, biar denger kateye / Anak perempuan gak usah merih (?) / Pokok asal bisa nulis dan bace / Biar sekolahnye di kelas tinggi / Ahirnye kerjenye di dapur juga

D: Babeh jangan bilang sembarang bilang / Perempuan sekarang haruslah maju / Kalau aye dapet ke kedokteran / Bisalah ngurusin anak dan cucu

43 Sopian contends that Silado's appointment was connected to the fact that the authority responsible for Aktuil's publishing license shifted from the West Java Regional War Authority to the Department of Information in 1970. Sopian, "Putus Dirundung Malang." 
In addition to including bonuses inside the magazine, there were other design changes. Later editions are in the larger A4 format and their contents are ordered into neatly arranged columns. The material still reveals a consistent interest in gazing at the West, but the way in which Indonesian performance is portrayed, especially its gender make-up, changed. In earlier editions, female performers are prominent. However, these women are never present in national spaces. They are either highly mobile - running from their parents, touring Europe-or posing in spaces notable for their lack of geographical distinction. The "pop" feeling of early editions exists outside the spaces of the nation. In later editions, the magazine begins to accord more page space to Indonesian male rock musicians and to address readers not only as youth, distinct from the authorities and their parents, but also as young rock fans, distanced from mass production and consumption of pop music.

\section{Producing Rock, Producing Middleness}

Over the decade following the cultural and political about-face starting on September 30, 1965, three distinct genres emerged. In the early 1970s, a new sound (that subsequently became known as dangdut) emerged, mixing iconically Eastern (Melayu) instrumentation and vocal styles with a rock aesthetic. Contrasting the overwhelmingly secular proclivities of rock and pop Indonesia, dangdut's consumption came to be closely linked to that of Islam. ${ }^{44}$ Scholarship on dangdut is varied in its interpretations of the genre; let it suffice it to note something on which several writers agree: throughout the New Order period, dangdut served as a sign of the unknowing and vulgar masses. ${ }^{45}$

Pop and rock developed separately along similar trajectories, but there were also distinctions between them. As mentioned, Western-style pop music was incorporated into the "effort towards moral transformation" required immediately after 1965.46 Subsequently, many of those performing this genre became quite closely associated with the ruling group, Golkar (Partai Golongan Karya, Party of the Functional Groups), and state media channels in general. Some pop Indonesia musicians took part in 1971 and 1977 in a so-called "artists' safari," part of Golkar's campaign to win elections. By virtue of their participation, artists were afforded entry to the state television station's program devoted to pop music, Aneka Ria Safari, which served them as a platform for promotion and for gaining other, better-paying gigs. This meant that state television, which was the sole terrestrial channel in the country up until 1989, played an important role in the mediation of pop.

Long-haired male musicians, by contrast, were not allowed to appear on Aneka Ria $S a$ fari, ${ }^{47}$ and this ban excluded a great many rock musicians from television broadcasts.

${ }^{44}$ Weintraub, Dangdut Stories, 27.

${ }^{45}$ See: Browne, The Gender Implications of Dangdut Kampungan; Ceres Pioquinto, "Dangdut at Sekaten: Female Representations in Live Performance," Review of Indonesian and Malayan Affairs 29, 1-2 (1995): 59-89; and Andrew Weintraub, "Dangdut Soul: Who Are 'the People' in Indonesian Popular Music?" Asian Journal of Communication 16, 4 (2006): 415.

${ }^{46}$ Mulyadi, Industri Musik Indonesia, 20.

${ }^{47}$ Mulyadi affirms as much on page 55 of his book, but on page 27 he elaborates that, although the proscription on long hair was the reason TVRI provided for banning Rhoma Irama from television broadcast, the excuse was considered dubious by many people. Mulyadi points out that long-haired males, 
Contrasting TVRI's exclusion of rock, later editions of Aktuil very much promoted the genre. ${ }^{48}$ Above, I recounted how earlier editions of the magazine sketch pop as a continuum stretching from the masculine West to feminine Indonesia. Long-haired Western male musicians were featured in early editions, but never Indonesian men, long-haired or otherwise. Later editions, however, depict Indonesia as a masculine realm, and include many images of long-haired Indonesian male musicians. Indeed, in an interview with Soleh Solihun, editor Remy Sylado confessed: "Ha ha ha. We Aktuil editors were all rock barat [Western rock] propagandists." 49

What propaganda, exactly, did Aktuil editors seek to espouse? Solihun avers that Aktuil's appraisals of local rock bands were full of hyperbole and liberally applied the term "superstar" to local rock performers; to retain readers' interest, Aktuil "transformed itself into a glittering stage." ${ }^{50}$ But the reason for the emergence of the figure of the Indonesian male rock musician in later editions is not entirely clear. Arguably, the increase in page space devoted to Indonesian male rock musicians may be seen to reflect the maturation of the Indonesian rock scene. The sounds of Western rock were more accessible in the 1970s than they had been in the previous decade, due to the proliferation of cassette-tape technology and the establishment of outfits like Aquarius Musikindo, which made and sold illegitimate copes of existing, copyrighted Western albums. A 2011 compilation album of progressive rock songs from the 1970s showcases a wide array of Indonesian cover bands from the $1970 \mathrm{~s} .{ }^{51}$ It suggests that the progressive turn in rock in the late-1960s and the passage of those sounds to young Indonesians' ears via pirated (bootleg) cassettes may have inspired a wave of amateur Indonesian progressive rock bands. Certainly, advertisements in later editions of Aktuil are suggestive of a healthy amateur rock scene. Many of these ads are for stores and schools specializing in musical instruments and music instruction.

It is important to stress that Aktuil was not exclusively devoted to rock. Its later editions adopted the slogan "for the young and the young at heart," ${ }^{2}$ and thus addressed youth in general, not just fans of rock and roll. In this way, Aktuil's later and earlier editions resemble one another. But there are important differences between them. Early editions address readers as a generation of consumers wellpositioned to reap the benefits of regime change, and later editions strive to distinguish readers as discerning consumers, critical of the regime. I see the emphasis

including the rock musicians Ahmad Albar and Ucok AKA, appeared on advertisements shown on TVRI. Mulyadi suggests that the real reason for banning Bimbo and Irama was political, as Bimbo's song "Tante Soen" was thought to depict the president's wife in unflattering light, and Irama had aligned himself with the PPP (Partai Persatuan Pembangunan, United Development Party). Nevertheless, the sense that rock existed outside of television broadcast persisted in Aktuil. Mulyadi, Industri Musik Indonesia, 55, 27.

${ }^{48}$ Such foregrounding coincided with the appointment of Remy Silado as editor and Maman Somtanri as designer in 1970. Sopian, "Putus Dirundung Malang."

49 Solihun, "Perjalanan Majalah Musik di Indonesia," 20.

${ }^{50}$ Bicara soal propaganda, Aktuil tidak bersikap setengah-setengah. Semua musisi rock dibilang superstar, mahabintang ... Aktuil telah berhasil menyulap dirinya jadi panggung gemerlap. Solihun, Ibid., 21 .

51 The three-LP set, Those Shaking, Shocking Days: Indonesian Hard, Psychedelic, Progressive Rock and Funk: 19701978, was released by the San Francisco-based label Now-Again Records. See M. Taufiqurrahman, "Long Live 1970s Indonesian Rock and Roll," The Jakarta Post, Sunday, April 1, 2011, http://www.thejakartapost.com/news/2011/04/10/long-live-1970s-indonesian-rock-and-roll.html, July 30, 2016.

52 Untuk Kaum Muda Dan Mereka Jang Berhati Muda. 
on rock as very much facilitating this new address, rather than as a reflection of developments in the rock scene taking place elsewhere. Rock was a vital part of the magazine's ability to address middle-class youth as culturally elevated, and as distinct from both the dangdut-consuming masses and from mass-produced pop. As mentioned, both rock and pop remained features of the magazine throughout the 1970s, but rock's increasing prominence coincided with efforts to position the magazine socially in new ways. Just as Aktuil began to include images of long-haired Indonesian musicians, it began to interpret these images for readers as indicators of musical quality.

In the 1970s, most rock bands performed in English, and this positioned the genre as culturally elevated. ${ }^{33}$ Aktuil added to such high-culture nuance by championing rock musicians while denigrating dangdut and pop. ${ }^{54}$ In 1973, for example, two published letters to the editor contrast musical quality and creative freedom with the (stifling) process of recording and the interests of recording companies. ${ }^{55}$ In 1974, a published complaint emerges about the band AMPY's cheap publicity stunts, and compares them to "selling soy sauce." ${ }^{6}$ In a published interview earlier that year, Bens Leo invited Jopie Item to assess the quality of Indonesian pop songs, and they both agreed that the commercially successful pop band Koes Plus did not deserve high ratings. ${ }^{57}$ Readers' interest in being seen as existing outside commercial production also emerges in some readers' memories of their experiences of reading Aktuil. For example, Soleh Solihun cites Aceng Abdullah's confession that, although as a young Aktuil reader in the 1970s he was self-conscious about desiring a Koes Plus album, he harbored a secret liking for that music, and in later life sought it out. ${ }^{58}$

Rock music's meanings as determined elsewhere almost certainly contributed to positioning the magazine as culturally elevated. Fornas avers that a globally circulating discourse of rock maintains the genre as a culturally elevated form, as distinct from mass-produced pop, and this bias clearly permeate interpretations of rock published in Aktuil. ${ }^{59}$ However, other closer-to-home developments also influenced the meanings of Aktuil's rock "propaganda." Not only do later editions of the magazine deride pop and dangdut, some also protest TVRI's ban on long-haired musicians. For example, in a 1973 interview, Sugiono MP asks the pop singer Anna Manthovani for her opinion on the TVRI ban, and Manthovani replies by describing the ban as "regrettable."60

Earlier that year the magazine included the following letter, which criticized TVRI:

\footnotetext{
${ }^{53}$ Arguably, foregrounding reading also advanced Aktuil's elitist agenda because it allowed the magazine to launch unanswerable attacks on dangdut, which was not represented in print (Weintraub, "Dangdut Soul," 211). The fact that no print media dedicated to celebrating dangdut existed until the appearance of Tabloid Dangdut in 1996 is testimony to the cultural force of rock and print's proximity in the pages of Aktuil (Solihun, "Perjalanan Majalah Musik di Indonesia," 69).

54 Weintraub, "Dangdut Soul," 416.

${ }^{55}$ See: M. Annabella, "Situ Harus Tahu, Ah!" Aktuil 127 (1973): 6; and Alex Mamahit Simatupang,

"Di Balik Layar Remaco," Aktuil 127 (1973): 6.

${ }^{56}$ MN Sofuan Hara-Hara, "Jerry Pengen Beken," Aktuil 139 (1974): 6.

${ }^{57}$ Bens Leo, "Obrolan Dengan Gitaris Senioren Jopie Item," Aktuil 138 (1974): 42-43.

58 Solihun, "Perjalanan Majalah Musik di Indonesia," 19.

59 Johan Fornas, "The Future of Rock: Discourses that Struggle to Define a Genre," Popular Music 14, 1 (1995): 111-25.

${ }^{60}$ Sugiono MP, "Wawancara Dengan Anna Manthovani," Aktuil 128 (1973): 30.
} 


\section{When Will TE-VE-ER-I Be Consistent?!?}

I would like to use this space to express my humble opinion. Keep in mind, it is the opinion of a stupid person. The problem is this: I have begun to notice that in a number of respects, TVRI (I always read it as TE-VE-ER-I, but I am an amateur in matters of proper pronunciation) has adopted positions that are utterly unacceptable, even to a stupid person like myself. The policy on long hair, for example. TE-VE-ER-I has decided that no male with long hair will be allowed to perform in the recording studio. Only if a football player happens to have long hair, and that player is playing in a match that is broadcast live on TVRI, will the station be party to broadcasting images of men with long hair. This was the reason given for why Bimbo [a pop group from Bandung] was banned from TVRI. About this matter, I want to ask, in all my stupidity: "What does TE-VE-ER-I want, and why is it discriminating against men with long hair?" Nia Gantini ${ }^{61}$

This sort of criticism demonstrates the sense that young people were beginning to develop in the 1970s that they were members of a dissenting middle class. They felt charged not only with pushing away from anticolonial rhetoric and embracing all the West had to offer (as they had been in the late-1960s), but also with setting themselves apart from those power-holders who had enabled them to do so. This reflects the evolution of student activists' political identities, and reveals how growing uncertainty about the regime was reflected not only in student protest and news magazines, ${ }^{62}$ but also in popular culture.

The middle-class youth that Aktuil addressed by no means constituted a significant political force capable of interfering with the government. Aktuil reached peak circulation just as the New Order regime was beginning to set down lasting roots. After a crackdown on student dissidents in 1974, hundreds of people were detained and twelve publications were banned. Flush with revenue from oil sales after global prices rose in 1971, the government implemented an economic policy that encouraged the growth of small and medium scale businesses, securing, according to Aspinall, the qualified support of the middle class:

Although the 1970s saw considerable discontent among groups with independent incomes and professional interests in a free public sphere (notably

${ }^{61}$ Kapan TE-VE-ER-I Mau Konsekwen?!? Melalui ruang ini saya hanya hendak mengemukakan pendapat yang terbatas pada scope yang mungkin bisa dianggap datang dari seorang yang amat bodoh seperti saya ini. Soalnya begini: dari beberapa hal yang saya perhatikan ternyata TVRI (saya selalu baca TE-VE-ERI, sebagai seorang awam) telah memperlihatkan beberapa jalan pikiran dan sikap yang tidak bias masuk akal seorang yang bodoh seperti saya. Lihat saja soal policy terhadap rambut panjang, alas an TE-VE-ER-I, kalau tidak di ruang studio, rambut gondrong bisa disiarkan, misalnya dalam sepak bola, yang nota bene berupa siaran langsung. Tapi trio Bimbo yang diCut begitu saja. Dalam soal ini saya yang bodoh bertanya2: "Apa sih maunya TE-VE-ER-I ini kok dalam menghadapi soal rambut panjang sampai bias punya sikap dan pemikiran diskriminasi?” Nia Gantini, “Kapan TE-VE-ER-I Mau Konsekwen?” Aktuil 123 (1973): 6.

${ }^{62}$ In 1972, Gunawan Mohamad wrote an article in Tempo entitled "Serving, with Criticism," expressing the avoidance of direct attack that was in vogue among supporters-turned-critics in the early $1970 \mathrm{~s}$. In it he posed the question, "What kind of criticism is wished for and permitted by the authorities?" and concluded with the advice: "Anyone who doesn't want to have his head split needs to choose wisdom over audacity." Steele, Wars Within, 58. On supporters-turned-critics' avoidance of direct attack, see Edward Aspinall, Opposing Suharto: Compromise, Resistance and Regime Change in Indonesia (Stanford: Stanford University Press, 2005), 24. 
private lawyers and journalists), overall the middle class remained small, insecure and worried about unrest ... Most saw little point in openly challenging the state when its supremacy was so clear and while it was delivering economic growth. ${ }^{63}$

Readers of Aktuil were among those who enjoyed the fruits of the economic growth, as evidenced by the increasingly abundant advertisements for musical instruments, fashion items, and music lessons that appeared in the magazine in the early to mid-1970s. They also enjoyed cultivating identities as discontented, critical citizens. While insignificant as a political opposition, Aktuil's positioning of its readers was politically significant in other ways. For one, its emphasis on rock created distance between its readers and TVRI, mass-produced music, and the consumption culture. It also ipso facto was rock's voice in the media. Rock relied on Aktuil for its elaboration, and the sense of rock consumers as a public could only flow from reading Aktuil. Later editions, then, do not just address readers as rock consumers. They also address rock consumers as readers. Securing this link between rock and reading (which I expand on below) was crucial because it bound the notion of belonging to a social middle not only to popular culture consumption but also to critique. To understand how it did so, we need to consider the social implications of the reorganization of the press in the early days of the New Order.

\section{The Reorganization of the Press}

In the first half of the 1960 s, most newspapers were linked to party politics and collectively known as "pers perjuangan" (lit. press of struggle), which Hill describes thus:

The 1950s and early sixties were characterized by a vibrant, often caustically partisan press, organized along party lines. Technologically and financially impoverished but richly committed to stimulating public debate and mobilizing public opinion, even if this brought it into direct conflict with government policies. ${ }^{64}$

This situation changed dramatically under the New Order. Hill writes that in March of 1965, twenty-nine newspapers had been closed due to their support of anticommunism. In the aftermath of October 1965, forty-six more newspapers were banned for supporting communism. ${ }^{65}$ By 1969, the number of extant newspapers and magazines had been reduced to half the 1964 level. ${ }^{66}$ Farid avers that the annihilation of the language of anti-imperialism in New Order-era public discourse was partly achieved through the speedy establishment of new systems for state control of the press. ${ }^{67}$

63 Ibid., 26.

${ }^{64}$ David Hill, The Press in New Order Indonesia (Nedlands: University of Western Australia Press, 1994$), 14$.

65 Ibid., 34.

66 Ibid., 15.

${ }^{67}$ Hilmar Farid, “Indonesia's Original Sin: Mass Killings and Capitalist Expansion, 1965-66," Inter-Asia Cultural Studies 6, 1 (2006): 3-16 
In this reorganized environment, journalists fell under a great degree of state surveillance. Moreover, news publications were no longer party organs and therefore imagined their readership in new ways. The reorganization of the press, then, gave rise not only to new kinds of journalistic writing but also forged new audiences for that writing. News publications' intended destination could no longer be the front porch of those who, by reading a particular newspaper, identified as a member of a particular political party. It had to be the front porch of those who, by choosing to read a particular newspaper, identified as a member of a social or demographic group.

As the existing body of scholarship on the New Order-era press makes clear, some of the flagship-quality publications of the period imagined their readership as a homogenous middle class. ${ }^{68}$ The New Order state fantasized that this middle class would comprise its loyal subjects. Journalists, and intellectuals more generally, were obliged to uphold the state developmentalist mission, and this obligation was enforced by daily threats to journalists, imprisonment of prominent figures, and periodic bannings of performances and publications. Nevertheless, small spaces were found by intellectuals to summon a critical position. In these small spaces, a sense of autonomy arose. For example, Romano's study found that journalists saw themselves not as loyal defenders of the state's development program, but as agents of social and political change. ${ }^{69}$ Steele found that Tempo's reports tended to depict the masses as victims of state development programs, rather than their beneficiaries. ${ }^{70}$

By reading across the body of work examining the press in the early New Order period, it is possible to gain a sense of a budding critical, middle-class reading public. However, one cannot gain a sense of how the emerging consumer culture may have propagated and sustained this public. Aktuil points to the important role played by an overlapping address - of consumers of Western pop and rock, and of readers-in marking out new spaces in which a critical middle-class sensibility could grow.

Understanding the confluence of the ideologies of rock and the press in the construction of a social middle requires discussion of the idioms of class distinction, kampungan and gedongan. The notion of genre publics already undergirds these idioms, which blossomed along with important dimensions of Indonesia's capitalist revolution-middle-class growth, the emergence of Jakarta as an "urban behemoth,"71 the depoliticization of the masses, and the expansion of the urban poor. Kampungan translates as "of the slums" or "of the village," while gedongan literally translates as "of the buildings." The terms also index musical taste regimes, and for this reason they have been central to scholarship about popular music: scholars generally agree that

\footnotetext{
${ }^{68}$ See: Ariel Heryanto, "Public Intellectuals, Media, and Democratization," in Challenging Authoritarianism in Southeast Asia; Comparing Indonesia and Malaysia, ed. Ariel Heryanto and Sumit K. Mandal (London and New York: Routledge Curzon, 2003), 41; Webb Keane, "Freedom and Blasphemy: On Indonesia Press Bans and Danish Cartoons," Public Culture 21, 1 (2009): 51; Janet Steele, Wars Within, 165-97.

${ }^{69}$ Romano, Politics and the Press in Indonesia: Understanding an Evolving Political Culture (London and New York: RoutledgeCurzon, 2003), 55-56.

${ }^{70}$ Steele, Wars Within, 157. People's faith in the value and existence of this critical news-reading public only came to light in retrospect, when widespread demonstrations erupted following the banning in 1994 of three newsmagazines - Tempo, Editor, and Detik. See: Heryanto, "Public Intellectuals, Media, and Democratization," 42; and Keane, "Freedom and Blasphemy," 52.

${ }^{71}$ Vedi R. Hadiz, "The Rise of Capital and the Necessity of Political Economy," Journal of Contemporary Asia, 43, 2 (2013): 211.
} 
the way in which kampungan-gedongan ordered popular music reflected the New Order's Western proclivities. Gedongan musical worlds resound with Western sounds (e.g., pop Indonesia and rock), ${ }^{72}$ while dangdut, a genre which gestures towards the East, serves as a sign of the kampungan, the unknowing and vulgar masses. ${ }^{73}$

Print media also used and reinforced these categories and their unequal social positions: gedongan's refinement was intimated in colorful derisions of kampungan's vulgarity, in the medium of print. ${ }^{74}$ Kampungan and gedongan, in other words, connect those who read with certain genres of popular music, and those who do not read with other genres. The argument I pursue here suggests that the term gedongan well captures the notion of middle-classness as a genre public. Gedongan accords a greater role to circulating texts than to an economic base in constituting the social middle, and it emphasizes the important role of the built environment in enabling people to "feel" the assemblies that such texts enabled them to imagine. Gedongan not only acknowledges the formative role of print in generating a middle-class assembly from a disparate collection of strangers, but also attends to the performative dimension of reading that made being middle class seem real.

Above, I stated that Aktuil foregrounded a rhetoric of print. This resulted from two developments in later editions of the magazine: the switch to new spelling, and the inclusion of a feature devoted to absurdist poetry. This latter development had the effect of bringing the carnivalesque possibilities of an overlapping address of readers and rock consumers into sharp focus, and enabled the magazine to draw on distinct legacies of well-educated nationalists and wild revolutionaries to propose a composite pemuda. Contrary to scholars who argue that pemuda was banished during the New Order (see my critiques of Siegel, above), or reassigned to loyalist types, ${ }^{75}$ I posit that the legacy of pemuda as agents of progressive social change continued to thrive in the pages of Aktuil.

\section{Aktuil's Reading Public and the Irreverent Pemuda}

In 1972, the government introduced a new spelling convention, referred to as "perfected spelling" (ejaan yang dispempurnaka, EYD, in which " $\mathrm{tj}$ " is exchanged for "c," "j" for "y," and "dj" for " $j$ "). Herein lies another difference between early and later editions. Early editions employ the old spelling and later editions use the new spelling.

In Aktuil, the new spelling serves to directly address a reading public because the magazine emphasizes the significance of considering how to correctly render names in the new spelling. Such considerations only matter to those who read and write. Nia

\footnotetext{
72 See: Philip Yampolsky, "Hati Yang Luka," Indonesia 47 (1989): 1-17; Emma Baulch, "Pop Melayu vs. Pop Indonesia: Marketeers, Producers and New Interpretations of a Genre into the 2000s," in Sonic Modernities in Southeast Asia, ed. Bart Barendregt (Leiden: Brill, 2014), 187-216.

73 Susan Browne, The Gender Implications of Dangdut Kampungan: Indonesian 'Low Class' Popular Music, Institute for Asian Studies Working Paper no. 109 (Clayton: Monash University Centre of Southeast Asian Studies, 2000); Andrew Weintraub, "Dangdut Soul," 411-31.

74 Ibid., 411.

${ }^{75}$ See Loren Ryter, "Pemuda Pancasila: The Last Loyalist Free Men of Suharto's Order?" Indonesia 66 (1998): 45-73.
} 
Gantini's letter, cited above, for example, includes an enquiry about how to correctly render the name "TVRI" into the new spelling, and an article on Renny Constantine notes that her name must now be spelled as Konstantine. Both pieces not only display a self-consciousness about writing and spelling, but also disgruntlement, directed at the "hypocritical" power-holders who continue to spell their names in the old waye.g., Soeharto instead of Suharto-or confuse the correct way to render TVRI into the new spelling. Zt writes:

Her name is in fact Renny Constantine, and looking at her narrow nose we can be certain that she has Western ancestry. But we must spell her name in the new way-even though those who require us to do so continue to spell their own names in the old way-so we have changed it to Renny Konstantin. ${ }^{76}$

Following her protestation of TVRI's banning long-haired performers from the studio, Gantini registers the following complaint:

And then there is the matter of how TVRI ought to be spelt. It turns out that TVRI's use of the new spelling lacks consistency and is sometimes incorrect. The way it spells TVRI is all over the place: TI-VI-ER-I. How shameful! It should either be T-E-VE-ER-I, or TI-VI-AR-AI. Provide a proper example, why don't you, to the young, aware, and critical generation. Thank you! Nia Gantini, Jalan Mandalawangi 149/15, Ciamis $^{77}$

The second development in the magazine that enables it to address directly a reading public relates to the irreverent and anti-establishmentarian literary content that emerged in later editions in the regular one-page poetry feature called "Puisi Mbeling" (and in which new spelling is employed). This feature was established in 1972 after editor Remy Silado began contributing his own poems in a style he called puisi mbeling (puisi $=$ poetry, mbeling $=$ a kind of strategic naughtiness),${ }^{78}$ prompting readers to send in their own poems in the same mbeling style. Some sources claim that Aktuil received up to three hundred such poems every month. ${ }^{79}$ Solihun cites the following letter to the editor, which captures some of puisi mbeling's appeal:

I am really interested in the Aktuil's mbeling poetry, which challenges the poetry of the Old Generation. I am a high school student, and that [Old Generation]

${ }^{76}$ Namanya sebenarnya Renny Constantine, dan memang ditinjau dari hidungnya yang mancung berani kita pastikan mempunyai darah campuran orang-orang Barat sana. Tapi karena disesuaikan dengan ejaan baru - yang baru polopornya bahkan tidak konsekwen mengganti nama mereka dengan ejab juga-maka kita gantilah menjadi Renny Konstantin. Zt, "Renny Konstantin," Aktuil 127 (1973): 19.

${ }^{77}$ Kemudian soal ejaan untuk huruf2 TVRI. Ternyata TE-VE-ER-I juga tidak konsekwen, dan nyeleweng dari EYD. Unutk TVRI ternyata kepalang masak dan tanggung, dengan dieja sebagai TI-VI-ER-I. (Maluin aje!) Kalau TVRI memang mau konsekwen si, maka untuk TVRI mestinya dieja T-E-VE-ER-I, atau TI_VI_AR_AI. Kasih dong contoh yang benar pada masyarakat, terutama pada generasi mudanaya yang se karang iñi benar-benar sudah melek dan kritis. Terimakasih! Nia Gantini, Jalan Mandalawangi 149/15, Ciamis. Gantini, "Kapan TE-VE-ER-I mau konsekwen?" 6.

78 "Dalam Bahasa Jawa, kata mbeling berarti nakal atau suka memberontak terhadap kemapanan dengan cara-cara yang menarik perhatian. Namun berbeda dengan kata urakan, yang dalam Bahasa Jawa lebih dekat dengan sikap kurangajar dan asal beda, kata mbeling mengandung unsur kecerdasan serta tanggungjawab pribadi,"(Wawancara [interview with] Remy Sylado, 19 Mei 2004). In Javanese, mbeling means naughty or rebellious. Unlike urakan, which infers rudeness and willfulness, mbeling carries overtones of cunning and strategy. See Sekapur Sirih, forward to Remy Sylado, Puisi Mbeling Remy Sylado (Jakarta: Kepustakaan Populer Gramedia, 2004), xi.

79 Ibid., xvi. 
poetry always gives me a headache. We have to memorize it in all its ridiculous detail. If you think about it, it has no quality! Thank you editor for your attention to this letter. ${ }^{80}$

Earlier in the essay, I noted that the "middleness" evinced by Aktuil is aptly conceptualized with Indonesian idioms of class distinction, kampungan and gedongan. However, puisi mbeling also extends understandings of such idioms to be gained from existing scholarship dealing with gedongan as a cultural form. Several scholars position gedongan as an imaginary constituted by elitist derisions of the masses in print media (including Aktuil). ${ }^{81}$ But Aktuil reveals the layers of an emerging gedongan sensibility; Aktuil's address was not consistently elitist-it oscillated between haughty derision of the masses and ludic irreverence. Such oscillation points to the new depictions of youth as historical agents in literature tailored to young middle-class consumers in the mid-1970s. Above I indicated that Aktuil's overlapping address of rock consumers and of readers created a new kind of youth ideal, in which distinct interpretations of pemuda associated with the 1928 generation of educated, nationalist youth and the generation who took up arms in the revolution were fused. This marriage is nowhere more evident than in the pemuda addressee heralded by puisi mbeling-he is both highly literate and obstinately wild. We have seen how the focus on rock enabled the magazine to launch attacks on dangdut as a way of establishing Aktuil's class position, and we have also seen how that focus marked Aktuil as critical, separate from mass production and state television. But puisi mbeling distinguishes Aktuil's reading public from others associated with realms of literary production. By including puisi mbeling in the magazine, readers are addressed not only as morally and socially elevated truth seekers, but also clever tricksters, as mbeling's carnivalesque manipulations of language not only hold the power-holders to account, but also poke fun at well known literary critics of the day. For example, mbeling poems published in Aktuil consistently mocked the literary journal Horison and members of the literary establishment associated with it. One poem in the mbeling style, by Mahawan, mocked HB Jassin, the editor of Horison, and another, by Estam Supardi, made fun of WS Rendra, one of the first poets of those who took part in the literary renaissance of the late-60s and early 70 s to gain fame.

The mbeling mockery of Rendra is funnier in Indonesian than its translation (provided on the next page), since it puns one of his well-known poems. Nevertheless, the reference to Rendra's shrunken penis retains some humor in translation, especially in light of what critic and translator Harry Aveling refers to as Rendra's poems' "excessive masculinity." 82

${ }^{80}$ Saya benar2 tertarik dengan Puisi Puisi Mbeling-nya Aktuil, yang benar-benar merupakan puisi tandingan dari puisinya Angkatan Tua yang cuma bisa bikin tambah pusing kepala saya sebagai pelajar sekolah lanjutan, dimana saya mesti hapal apa itu susunan sajak dan tetek bengek lainnya yang kalau kita pikir pikir tidak ada mutunya. Terimakasih atas perhatian redaksi. Letter from Soesanto Santoso, Komplek PasDam, Jakarta, published in Aktuil 109 (1973), and cited in Solihun, "Perjalanan Majalah Musik di Indonesia," 16.

${ }^{81}$ Susan Browne, The Gender Implications of Dangdut Kampungan: Indonesian 'low class' popular music (Clayton: Monash University Centre of Southeast Asian Studies, Institue for Asian Studies Workding Paper no. 109, 2000), 10; Andrew N. Weintraub, "Dangdut Soul: Who are 'the People' in Indonesian Popular Music?" Asian Joumal of Communication 16:4 (2006): 411.

${ }^{82}$ Harry Aveling, "Contemporary Indonesian Poetry," in Harry Aveling, ed., Contemporary Indonesian Poetry (St. Lucia: University of Queensland Press, 1975), xviii. 
good evening mr. rendra

oh, you are male aren't you sir?

your cock,

sir,

has flopped ${ }^{83}$

According to Seno Gumira Ajidarma, puisi mbeling played an important role in young people's lives in the 1970s. "We may doubt that any of this [mbeling writing] constitutes Indonesian literature, but the fact is that Aktuil was the only kind of literature that mattered to teens at that time. They had no regard at all for the much revered Horison." ${ }^{84}$ Aktuil's impact, moreover, extended beyond the realm of its readers to influence the style of a number of writers, such as Yudhistira Massardi, ${ }^{85}$ whose works Farid describes as "highly carnivalesque."

It is important not to overstate the significance of Aktuil's literary dimensions. Existing studies of Aktuil privilege written forms in assessments of the magazine's critiques, and focus on the role of Remy Sylado as a key mediator of a critical youth public. Yet, while undertaking the research for this essay, I noted with fascination readers' enthusiasm for not only reading Aktuil, but also wearing and inhabiting it. For them, being a rock fan was not about publicly displaying their affinity for reading and writing in the Aktuil style. It was, rather, about "becoming" rock by wearing flares and plastering their bedroom walls with Aktuil posters, for example. These readers' testimonies reveal the way commodities enlivened ideologies of rock and the press. Aktuil did not just herald the composite pemuda, but also created space for this composite in a world full of commodities, and threw light on the performative dimension of reading that made being middle class seem real.

\section{Real Paths for the Circulation of Discourse}

On opening the cover of Aktuil 128, 1973, readers are greeted by a full-page image of spectacularly flared white jeans. Indeed, later editions are generously sprinkled with full-page advertisements for various fashion items, primarily flared jeans (using striking images), but also other consumer goods, such as musical instruments and

${ }^{83}$ selamat malam tuan rendra / oh, tuan laki-laki bukan? / burung / tuan / kendor, kedodor. Poem by Estam Supardi, published in Aktuil 136 (1974), cited in Sopian, "Putus Dirundung Malang."

84 "Kita boleh ragu, bahwa ini semua ada hubungannya dengan kesusasteraan Indonesia, tapi kita harus percaya bahwa tiada 'sastra' lain bagi kaum remaja saat itu selain Aktuil yang ditunggu-tunggu bukan Horison yang waktu itu jadi panutan." Cited in Sylado, Puisi Mbeling Remy Sylado, xv, from Seno Gumira Ajidarma, "Menghujat Generasi Munafi: Mbelingisme 23761" [Denouncing the hypocritical generation: 23761's Mbelingism], introduction to Remy Sylado, Potret Mbeling: Kumpulan Puisi (Jakarta: Jakarta Jakarta, undated).

${ }^{85}$ Seno Gumira Ajidarma, Abdul Hadi WM, the three Massardis (Noorca, Yudhistira, and Adi), Efix Mulyadi, Kurniawan Junaedi, and Edy Herwanto are cited as writers who were supportive of Remy's mbeling poetry. See Sylado, Puisi Mbeling Remy Sylado, xvi.

${ }^{86}$ Farid, "Meronta dan Berontak: Pemuda dalam Sastra Indonesia," hilmarfarid.com/wp/meronta-danberontak-pemuda-dalam-sastra-indonesia/11/09/15, July 12, 2016. See also: Benedict Anderson, Language and Power: Exploring Political Cultures in Indonesia (Ithaca: Cornell University Press, 1990), 194-237; Sylado, Puisi Mbeling Remy Sylado, xvi; and Savitri Scherer, "Yudhistira Ardi Noegraha: Social Attitudes in the Works of a Popular Writer," Indonesia 31 (1981): 31-52. 
music lessons. In contrast to early editions, 1969-70, which were heavily textual, ${ }^{87}$ later editions sketched the sartorial dimensions of pemuda. They articulated pemuda not only by critiquing the state and the literary establishment, but also by celebrating the possibilities an emerging consumer culture offered for embodying youth in new ways.

The importance of materials and images to readers' experiences of reading Aktuil can be partly attributed to designer Maman Somantri, who implemented several changes on his appointment in $1970 .{ }^{88}$ As well as enlarging the magazine's format, Somantri altered the color contrast, and this had the effect of making the images appear to leap off the page. Finally, he introduced bonuses, including stickers featuring catchy phrases (e.g., "Slow But Sure," "Don't Speed, Gas is Costly"). ${ }^{89}$ Existing studies of Aktuil privilege written forms in assessments of the magazine, and focus on the role of Remy Silado as a key mediator of a critical youth public. ${ }^{90}$ Somantri's role as designer is somewhat neglected. But I submit that it was not only Silado's writing, but also Maman Somatri's posters and stickers, which prompted the sudden increase in sales in the early 1970s. They certainly feature prominently in readers' recollections. Readers' enthusiasm for these items is suggestive of their role in forging what Michael Warner refers to as "real paths for the circulation of discourse." ${ }^{91}$ The magazine's advertisements afforded the rock-consuming, reading pemuda a dress style that allowed him to be accommodated within a world of Westernoriented consumption, and bonuses furnished readers with the materials with which to write Aktuil into the spaces in which they lived.

Warner argues that it is not just modes of address, enabling people to imagine their membership in an assembly of strangers, that sustain publics, but rather a to-ing and fro-ing between such abstraction, on the one hand, and a concrete embodiment, on the other. Public discourse, that is, relies for its efficacy not just on the work of the imagination but also on the labor of emplacement. He writes:

From the concrete experience of a world in which available forms circulate, one projects a public ... Writing to a public helps to make a world, insofar as the object of address is brought into being partly by postulating and characterizing it. This performative ability depends, however, on that object's being not entirely fictitious-not postulated merely, but recognized as a real path for the circulation of discourse. ${ }^{92}$

Real paths for the circulation of Aktuil discourse were forged by the materials included in the magazine. These materials enabled readers to perform their identities as rock-consuming readers in their communities, their homes, and their bedrooms (and such performances resemble what Warner refers to as bringing a "hope of transformation" into a "scene of practical possibility"). ${ }^{93}$ As touched on above, flared

\footnotetext{
${ }^{87}$ The early editions included only one text advertisement, and that was for a bus company.

${ }^{88}$ Soleh Solihun, "Perjalanan Majalah Musik di Indonesia," 8.

${ }^{89} \mathrm{http}: / /$ twicsy.com/i/CjxfP, August 4, 2015.

${ }_{90}$ Mulyadi, Industri Musik Indonesia; Sylado, Puisi Mbeling Remy Sylado; and Sopian, "Putus Dirundung Malang."

91 Warner, "Publics and Counterpublics," 62.

92 Ibid., 63-64.

${ }^{93}$ Ibid., 69.
} 
jeans ("flares") loomed large in my interviewees' recollections of what it meant to be a rock fan. One informant explained to me how the James Brown cover band The Rollies was considered to be a rock band because they came from Bandung and wore flares. Flicking through the photocopied editions I had brought to the interview, he stopped at the above-mentioned full-page advertisement featuring an image of white flares. "See that?" he pointed, turning the magazine toward me. "That is what we thought of as rock." 94

Moreover, it was not just flares that readers used to advertise their identities as Aktuil readers; possessing and displaying the magazine itself signaled membership. Sopian cites Bandung journalist Yusran Pare's recollections of carrying a copy of Aktuil as he navigated Bandung's streets, and the important role the magazine played in identifying him as, in his words, a "real" youth, in eliciting in him a sense of belonging to a particularly authentic kind of youth community, members of which became connected to one another by inhabiting Aktuil's real and imagined paths of circulation. In other words, in Pare's recollection, it was not enough to simply imagine one's membership in a new kind of youth assembly while reading Aktuil in the comfort of one's home. One had to carry the magazine as one ventured out into the public spaces of the city. ${ }^{95}$

As well as providing a link to an imagined community of readers, then, Aktuil furnished youth with sartorial equipment that gave them a sense of power over public space. But its social life did not end there, for Aktuil also contained a host of materials that could be removed from the magazine's spine and inserted into domestic or intimate spaces: stickers, iron-ons, and posters. These objects quickly became divorced from the magazine and were pasted onto walls and tee shirts in all corners of the archipelago. Two of my informants grew up in Denpasar, and another in Jayapura, and both recalled the importance of Aktuil's centerfold posters in their teen years. ${ }^{96}$ Dek Gun, for example, recounted how he had based his decision to part with Rp500 for a copy of Aktuil on the centerfold for that month. He used Aktuil's centerfolds to adorn his bedroom walls, which, he confessed, had been "full rock" plastered with Aktuil centerfolds in the 1970s. As Warner argues, print alone is not sufficient for publication in the modern sense. "Not texts themselves create publics, but the concatenation of texts through time." ${ }^{\prime 7}$ Reading publics are sustained not only by writing, but by sequences of related texts that enable the readers' engagements with public discourse to be performed and felt.

${ }_{94}$ Author's interviews: Dek Gun, Denpasar, October 12, 2013; and Andy F. Noya, Jakarta, October 9, 2009.

95 Sopian writes: "In a short space of time, Aktuil's attributes found their way into all corners of the city of Bandung, and Aktuil quickly became an important status symbol for Bandung youth. 'It felt like you weren't a proper teen if you didn't have your copy of Aktuil with you,' said Y usran Pare [a Bandung journalist], who, as a boy in the 1970 s, would beg his father to buy him a copy of Aktuil." (Dalam tempo cepat, atribut Aktuil menyebar ke pelosok kota; dan Aktuil tak urung jadi simbol sosial anak muda kota Bandung. "Rasanya belum menjadi anak muda kota kalau tidak menenteng Aktuil," kata Yusran Pare, penanggung jawab harian Metro Bandung, yang pada 1980-an menjadi penjaga gawang rubrik kebudayaan di Bandung Pos. Dia sendiri, di awal 1970, sudah biasa merengek pada ayahnya untuk dibelikan Aktuil. Sopian, "Putus Dirundung Malang."

${ }^{96}$ Author's interviews: Made Widiantara, Denpasar, December 2, 2013; Dek Gun; and Andy F Noya.

${ }^{97}$ Warner, "Publics and Counterpublics," 62. 
Warner's insights into the multiple texts that are required for publics to sustain and endure are useful not because they offer proof that Aktuil readers constituted a public in accordance with scholarly definitions. They are helpful, rather, because they open space for alternative readings of the political effects of the proliferation of consumer goods that proceeded with economic growth in the 1970s. Aktuil shines a light on how reading critical texts was closely linked to the consumption of fashion-a link that is as salient to the analysis of contemporary politics as it is to that of the 1970s. We should not assume a direct correlation between the enjoyment of the fruits of economic growth and support for the power-holders who deliver it. It is, indeed, possible that rock's critical potential was subverted by readers' consumerist urges. However, it is also possible that Aktuil's unique interpretation of rock provided a frame by which youths could understand commodities as being intrinsically linked to longstanding narratives of their historical agency.

By embodying the rock-consuming reader, young middle-class men were not just hedonistically and apolitically consuming. They were piecing together an infrastructure that enabled the articulation of ideal democratic personhood in years to come, for elements of middle-class culture forged during the New Order period left indelible traces on contemporary politics. One need not look far to find such traces; they can be found in Joko Widodo's repeated efforts to position himself as proximate to rock. As governor of Jakarta, Jokowi highlighted his love of rock by attending a Metallica concert, and by being photographed wearing a Napalm Death (a British heavy metal band) tee shirt. ${ }^{98}$ During his election campaign, he took measures to ensure that the prominent Indonesian rock band Slank endorsed his candidacy. ${ }^{99} \mathrm{We}$ cannot begin to understand the implications of Jokowi's choice for contemporary discourses of democracy without revisiting the Indonesian middle-class consumer culture in which Indonesian interpretations of rock first appeared. When we do so, as I have in this essay, we find that rock played a profound role in rearticulating longstanding ideal tropes of youth as critical and politically active.

Charles Hirschkind's study of cassette sermons and their roles in laying the sensory and moral foundations for Egypt's Islamic revival is usefully invoked at this point. Hirschkind argues against scholarly literature on contemporary Islam that seeks to measure the Islamic Revival's democratic credentials and potential by ascertaining the extent to which it is amenable to public reason. He argues that

[C]assette-recorded sermons ... are not oriented towards politics as it is conventionally understood: their purpose is not to influence the formation of state policy or to mobilize voting blocs behind party platforms. Rather, the activities that constitute the public arena I describe as political are in a way close to the sense Hannah Arendt (1958) gives to the term: the activities of ordinary citizens who, through the exercise of their agency in contexts of public

${ }^{98}$ See: Dom Lawson, “Joko 'Jokowi’ Widodo's Metal Manifesto," The Guardian, July 11, 2014, http://www.theguardian.com/music/2014/jul/11/joko-jokowi-widodos-metal-manifesto, accessed June 4, 2015; and Cal Rednib, "Joko Widodo Loves Napalm Death, Devil Horns, and Sticking Up for the Little Guy," Vice, April 1, 2014, http://www.vice.com/read/meet-jokowi-indonesias-probable-next-president, accessed June 4, 2015.

99 Emma Baulch, "Pop Musicians, Soft Power and Indonesian Democracy," Asian Creative Transformations blog post (2014), http://www.creativetransformations.asia/2014/09/pop-musicianssoft-power-and-indonesian-democracy/, accessed October 2, 2014. 
interaction, shape the conditions of their collective existence ... [T] he affects and sensibilities honed through popular media practices such as listening to cassette sermons are as infrastructural to politics and public reason as are markets, associations, formal institutions, and information networks. ${ }^{100}$

The composite of the wild and literate rock-loving, reading pemuda that emerged from later editions of Aktuil is, I posit, similarly infrastructural to Indonesian politics. $\mathrm{He}$ can be seen at work in more recent history, first, in the student 1998 student movement that contributed to Suharto's downfall and second, in the election campaign that swept Joko Widodo to the presidency. Lee, for example, argues that activists' affinities with a raggedy dress style reflected their interest in combining the pure and moral persona of the 1928 generation with the "revolutionary charge" of the 1945 generation of pemuda. She writes:

In 1998, the pemuda label underwent a deliberate resignification, harkening back to the glorious past of revolutionary youth who participated in anticolonial struggle, rather than the lower-class "angry young man" or thugs for hire that pemuda had come to mean during the New Order. In reconciling the moral and elite persona of the student with the revolutionary charge of the pemuda, the body of the student activist emerged as a new, and yet familiar, identity. ${ }^{101}$

Indeed, a common perception among scholars is that the New Order regime succeeded in defusing pemuda's revolutionary potential. As mentioned earlier, Siegel argues that the increasing prevalence of the term remaja in the 1970s was a function of the New Order's depoliticization program, and Ryter suggests that the rise to prominence of vigilante groups employing the term pemuda "during the late Soeharto era is a consequence of the need (and the effort since the early New Order) to transform the revolutionary nationalism of pemuda ... of the post-independence period into a nationalism expressed through loyalty to the state." 102 In light of this picture, Lee's interpretation of the 1990s students' melding of the "moral and elite persona of the student with the revolutionary charge of pemuda" as a resignification is understandable. ${ }^{103}$ But this synthesis already had historical precedent in Aktuil's rockscape. Rather than reclaiming pemuda from Soeharto's paid thugs, the students were dancing to Aktuil's tune: the song of the literate, wild, long-haired youth-not a loyalist and a thug, but a sharp-witted critic and commentator.

\section{Negotiating Politics}

On June 21, 1994, Suharto's Ministry of Information banned three newsweeklies: Tempo, DeTik, and Editor. Over the six months to follow, no fewer than 170 demonstrations protesting the bans erupted across the country. Such mobilization was unprecedented in the New Order period, and Heryanto and Keane argue that it served

\footnotetext{
${ }^{100}$ Hirschkind, The Ethical Soundscape, 8.

${ }^{101}$ Lee, "Styling the Revolution," 936.

102 Siegel, Solo in the New Order, 201.

${ }^{103}$ Lee, "Styling the Revolution," 8.
} 
as an important catalyst for Suharto's eventual overthrow. ${ }^{104}$ Notably, too, some analysts contend that both the bans and the protests indicate an increasing middleclass assertiveness and ability to mobilize en masse:

Instead of displaying its prowess, the ban indicates the regime's paranoia about the assertiveness of emerging middle-class intellectuals and their power base, the mass media ... The protests were a predominantly middle-class event because that was the single most important characteristic of the protesters that came to the fore, surpassing differences of ethnicity, gender, profession, religious, or ideological orientation. ${ }^{105}$

The widespread demonstrations protesting the bans of Tempo, Detik, and Editor revealed the symbolic importance the press had come to assume in middle-class political imaginaries. They demonstrated that despite the tightly controlled New Order press environment, and its orientation to commercial, rather than party political, ends (unlike the press of the preceding period), it had nonetheless evinced in readers a sense of their membership of an emerging collectivity of critical middle-class subjects. Heryanto identifies a broader coming together of two processes to create the historical conditions conducive to building such imagined collectivities:

The first is the long-lasting and prolific reproduction of myths about selfless and truth-seeking public intellectuals as embodied in the university student, academic, and journalist activist. The second is the expansion of capitalist industrialization under heavy militarist rule that has delivered sustained economic growth but at the expense of human rights. ${ }^{106}$

In a similar vein, I have argued that Aktuil reveals how, despite all attempts to depoliticize them, youth held tight to preexisting tropes of their historical agency as they navigated the new press environment and the pro-West consumer culture that the state hoped would secure their loyalty and subservience.

In some respects, this argument rides the wake of Heryanto's insights into the close links between the press and middle-classness in the New Order period. However, it also extends them, by demonstrating that popular music and the broader consumer culture it inhabited were as crucial as was the press to the making of middle-classness.

The consolidation of the idioms kampungan and gedongan in this period provides good evidence of the salience of overlapping discourses of print and popular music in the constitution of a social middle. It also underscores their mythical, but by no means immaterial, dimensions: by way of flares, posters, and stickers, gedongan became firmly embodied. The picture that emerges is quite a far cry from one in which the middle class was "hammered into political ineffectiveness." The deft manipulation of the pemuda trope in Aktuil suggests that middle-class youth were politically astute, and the widespread demonstrations after the banning of Tempo, Detik, and Editor surely attest

104 "The Tempo demonstrations were some of the first serious open challenges to the regime's legitimacy, and some later observers considered them to have played a significant role in the loss of authority that helped precipitate President Suharto's eventual fall from power in 1998." Keane, "Freedom and

Bleasphemy," 53. See also Heryanto, "Public Intellectuals, Media, and Democratization," 41-42.

${ }^{105}$ Heryanto, "Public Intellectuals, Media, and Democratization," 41-42.

106 Heryanto, "Public Intellectuals, Media, and Democratization," 51. 
to these youths' considerable degree of political efficacy. By the 1990s, a middle-class reading public had become a significant political force.

By arguing as much, this essay aims not just at historical revision; it also means to intervene in debates about contemporary Indonesian politics. As discussed in the introduction, in recent years, the most influential exchanges taking place in the English language about contemporary Indonesian politics have centered on debates between political economists and those adopting pluralist approaches to understanding the qualities of Indonesia's democratic system. ${ }^{107}$ What strikes me about these debates, and the broader bodies of literature that feed them, is the absence of everyday life-language, food, sound, images, and bodies-and the sociolinguists, visual anthropologists, and ethnomusicologists who study those dynamics. This absence touches on a critique that has been launched now and again at those who seek to grasp the big picture of the Indonesian polity. In a review of the collection Producing Indonesia, for example, John Sidel avers that as political scientists have been accorded an increasingly privileged role in analyzing the political, certain important puzzles about Indonesian democracy remain unanswered, precisely because they cannot be answered with political science tools: "[A]s mainstream political scientists continue to narrow their assumptions, methods, categories of analysis, and conception of 'politics' to dis-embedded individuals and formal institutions, such questions about Indonesian politics remain unanswered and unanswerable within the discipline." 108

I offer a qualified endorsement of Sidel's critique; it is qualified because the unanswered puzzles he lists-the rise and decline of political Islam, the absence of communal violence, the decline of anti-Chinese violence, and contemporary populism-are all topics that have been studied and written about by people working out of political science, including some of those penning macro accounts in the very book Sidel reviews. ${ }^{109}$ Plenty of political scientists diligently employ rigorous ethnographic methods to follow developments on the ground as they unfold. Sidel is right, though, to observe that when political scientists are entrusted with a privileged role in analyzing politics, the definition of politics and the political sphere narrows, and what this risks is the disappearance from political analysis of those dimensions of public life that political science is not equipped to study.

Political scientists have not always been exclusively responsible for interpreting Indonesian politics. The seminal volume that bears this as its title (Interpreting

${ }^{107}$ For example, see: Vedi Hadiz, ed., "Special Feature Section: Capitalism and Indonesia's Democracy," Journal of Contemporary Asia 43, 2 (2013); and Michele Ford and Thomas B. Pepinsky, "Beyond Oligarchy? Critical Exchanges on Political Power and Material Inequality in Indonesia," in "Special Issue: Wealth, Power, and Contemporary Indonesian Politics," ed. Michele Ford and Thomas B. Pepinsky, Indonesia 96 (October 2013): 1-9.

${ }^{108}$ John Sidel and Adrian Vickers, review essays of Producing Indonesia-The State of the Field of Indonesian Studies, with a response from Eric Tagliacozzo, in Sojoum: Joumal of Social Issues in Southeast Asia 30, 1 (2015): 256-70.

${ }^{109}$ Eric Tagliacozzo, ed., Producing Indonesia-The State of the Field of Indonesian Studies (Ithaca: Cornell Southeast Asia Program Publications, 2014). 
Indonesian Politics), serves as a good example of multidisciplinary debate about postrevolutionary Indonesian politics: it includes two chapters by anthropologists. ${ }^{110}$

In their introduction to a special issue of this journal on political power and material inequality, Ford and Pepinsky contend that the model Interpreting Indonesian Politics presents deserves to be emulated. ${ }^{111}$ I agree with them, but not because "it not only applied existing theoretical perspectives to Indonesia, but refined theories and concepts, and generated new ones, from a close understanding of the Indonesian case"; this would seem to be a universal obligation of any good post-exceptionalist area studies scholar. Rather, it needs to be emulated because to do so is to resist the narrowing of the scope for examining of Indonesian politics.

As Judith Butler argues, "to set the 'norms' of political life in advance is to prefigure the kinds of practices which will qualify as the political and it is to seek to negotiate politics outside of a history which is always to a certain extent opaque to us in the moment of action." 112 In this vein, the kind of singularity suggested by Winters's assertion that "the starting point for understanding contemporary Indonesian politics is the observation that extreme material inequality necessarily produces extreme political inequality" needs to be challenged. ${ }^{113}$ Observations about patterns of wealth accumulation will not afford much insight into the contexts in which new political ideas emerge, or into the broader social imaginaries to which they give rise, including their historical significance. Understanding this requires a multidisciplinary approach, using a range of conceptual tools, including that of publics. Certainly, when the middle class is conceptualized as an imaginary arising from texts in circulation, rather than as an element of political-economic structure, the ideational roots of those societal forces that pushed for, and achieved, regime change in 1998 come into sharper focus.

110 Benedict R. O'G. Anderson and Audrey Kahin, eds., Interpreting Indonesian Politics: Thirteen Contributions to the Debate (Ithaca: Cornell Southeast Asia Program Publications, Interim Report Series, 1982).

${ }^{111}$ Ford and Pepinsky "Beyond Oligarchy? Critical Exchanges on Political Power and Material Inequality in Indonesia," 9.

112 Cited in Jodi Dean, "Cybersalons and Civil Society: Rethinking the Public Sphere in Transnational Technoculture," Public Culture 13, 2 (2001): 250.

113 Winters, "Oligarchy and Democracy in Indonesia," 12. 
